\title{
Selenium supplementation prevents DNA damage in ram spermatozoa
}

\author{
Carla Fredrichsen Moya ${ }^{1^{*}}$ (๑) Marcelo Piagentini ${ }^{2}$ Danilo da Cunha Silva ${ }^{3}[$

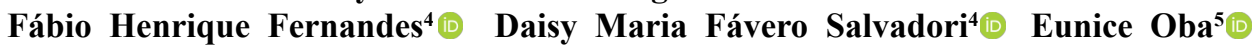

${ }^{1}$ Universidade Estadual do Centro-Oeste (UNICENTRO), 85040-167, Campus Cedeteg, Guarapuava, PR, Brasil. E-mail:carlafredrichsen@yahoo.com.br. ${ }^{*}$ Corresponding author.

${ }^{2}$ Faculdade Eduvale, Associação Educacional do Vale da Jurumirim, Avaré, SP, Brasil.

${ }^{3}$ Veterinário Autônomo, Avaré, SP, Brasil.

${ }^{4}$ Faculdade de Medicina (FM), Universidade Estadual Paulista "Júlio de Mesquita Filho" (UNESP), Botucatu, SP, Brasil.

${ }^{5}$ Faculdade de Medicina Veterinária e Zootecnia (FMVZ), Universidade Estadual Paulista “Júlio de Mesquita Filho” (UNESP), Botucatu, SP, Brasil.

ABSTRACT: In the present study, we aimed to evaluate the effects of different concentrations of selenium (Se) ovine nutritional supplementation on spermatozoa DNA integrity. Thirty male ovines (age: 10 months) were used. They were fed with hay and ram food in an intensive system, which was divided into stalls ( $5 \mathrm{~m}$ long and $3 \mathrm{~m}$ wide) with feeding troughs, and had ad libitum access to food and water. Ovines in group 1 (G1, the negative control) received mineral salt supplementation without Se; ovines in G2 received the same mineral salt mixed with $5 \mathrm{mg}$ Se (as sodium selenite)/kg mineral supplement;ovines in G3 received $10 \mathrm{mg} \mathrm{Se} / \mathrm{kg}$ mineral supplement; ovines in G4 received $15 \mathrm{mg}$ Se/kg mineral supplement; and ovines in G5 received $20 \mathrm{mg}$ Se/kg mineral supplement. Ovines in all groups remained untreated for 14 days, followed by a treatment period of 56 days. Semen samples were obtained by electroejaculation. The DNA damage in semen samples was evaluated using the comet assay. The experimental design was implemented using a $5 \times 5$ Latin Square, i.e., five treatments and five experimental periods. The mean differences were compared using Tukey's test at a significance level of 5\%. The control group (G1) showed a high percentage of DNA damage compared to the Se-treated groups (G2-G5). Therefore, Se supplementation could decrease the basal level of DNA damage in sperm cells, suggesting that Se might exert protective effects on sperm DNA.

Key words: chemoprevention, comet assay, semen, ovine.

Suplementação com selênio previne danos ao DNA espermático de ovinos

RESUMO: O presente estudo teve por objetivo avaliar os efeitos da suplementação mineral com diferentes concentrações de selênio (Se) sobre a integridade de DNA espermático de ovinos. Utilizaram-se 30 machos, com 10 meses de idade. Eles foram mantidos em sistema intensivo, sendo alimentados com feno e ração própria para ovinos, divididos em baias $(5 \mathrm{~m} \times 3 \mathrm{~m})$, com cochos e água ad libitum. Os ovinos do grupo 1 (G1=controle negativo) receberam suplementação de sal mineral sem a adição de Se, os animais do G2 receberam a mesma mistura mineral, porém com $5 \mathrm{mg}$ de Se (selenito de sódio)/ $\mathrm{kg}$ mistura mineral, os ovinos do G3 receberam $10 \mathrm{mg}$ Se/kg mistura, os animais do G4 receberam $15 \mathrm{mg}$ Se/kg mistura, os do G5 receberam $20 \mathrm{mg} \mathrm{Se} / \mathrm{kg}$ mistura. Os ovinos de todos os grupos passaram por um período de adaptação de 14 dias, seguido por um período de tratamento de 56 dias. O sêmen foi colhido por meio de eletroejaculação. A integridade do DNA espermático foi avaliada por meio do teste de cometa. O modelo experimental utilizado foi Quadrado Latino $5 \times 5$, com cinco grupos e cinco perídos experimentais. A diferença entre as médias foi analisada pelo teste de Tukey, com 5\% de nível de significância. O grupo controle (G1) apresentou elevada porcentagem de danos quando comparada aos demais grupos de tratamentos (G2 a G5). Portanto, a suplementação de Se diminui o nivel de danos ao DNA espermáticos, sugerindo que o Se pode exercer efeitos protetores sobre o DNA dos espermatozoides de ovinos.

Palavras-chave: quimioprevenção, teste do cometa, sêmen, ovino.

\section{INTRODUCTION}

Sheep industry represents an important productive sector of wool for garments, meat, dairy, and leather for human consumption (SCHWAB,
2011). In an ovine herd, the ram is mainly responsible for genetically improving the stock, owing to its capacity to mount more than 35 females under natural conditions during a breeding season (MANDIKI et al., 1998). Therefore, selection of ram breeders 
with high fertility is important for ovine production (MATOS et al., 1992). In this context, the assessment of sperm DNA integrity is quite relevant, wherein fertile sperms must have a stable DNA capable of decondensation at the appropriate time of fertilization, while maintaining the genetic codification without mutations (AGARWAL \& ALLAMANENI, 2005).

Among the essential trace minerals, selenium (Se) represents a key element for spermatogenesis and male fertility, where it improves reproductive health (BOITANI \& PUGLISI, 2009, HAWKES \& TUREK, 2001). The main sources of Se routinely used for animal supplementation are sodium selenite and selenate as inorganic Se, and Se-enriched yeast (Se-yeast) as organic Se (PETRERA et al., 2009). However, studies on the effects of this micronutrient and related minerals on ovine reproduction are still scarce. Therefore, the investigation of genetic changes in ram sperm is important for ovine herd improvement. Herein, we used the comet assay (single-cell gel electrophoresis assay) to evaluate the effects of Se-enriched diets on ram sperm DNA integrity. Comet assay is a shortduration and low-cost technique that can detect single- and double-strand breaks and alkali-labile sites in DNA (KOPPEN et al., 2017).

In reference to the above, the present study aimed to evaluate the effects of different concentrations of selenium (Se) ovine nutritional supplementation on spermatozoa DNA integrity.

\section{MATERIALS AND METHODS}

All experimental procedures were approved by the Institutional Animal Care and Use Committee (Protocol 180/2014) at the São Paulo State University - UNESP, Botucatu, São Paulo State, Brazil. The experimental conditions, endoparasite and ectoparasite vaccine control, and geographic location of the present study were the same as described by PIAGENTINI et al. (2017).

The experimental design of this study was developed through $5 \times 5$ Latin square design, with five treatments and five repetitions for the experimental period. Thirty ten-month-old, sexually mature rams (Ovis aries) (HULET \& SHELTON, 2004) were distributed randomly into five groups $(n=6)$ and fed hay and ram food (Allnova Fanton Animal Nutrition Industry, Brazil) in an intensive system, which was divided into masonry stalls ( $5 \mathrm{~m}$ long and $3 \mathrm{~m}$ wide) with feeding troughs and provided ad libitum access to food and water. Ovines in group 1 (G1; the negative control) received mineral salt supplementation without Se; ovines in $\mathrm{G} 2$ received the same mineral salt mixed with $5 \mathrm{mg}$ Se (sodium selenite) $/ \mathrm{kg}$ mineral supplement; ovines in G3 received $10 \mathrm{mg} \mathrm{Se} / \mathrm{kg}$ mineral supplement; ovines in G4 received $15 \mathrm{mg} \mathrm{Se} /$ $\mathrm{kg}$ mineral supplement; and ovines in G5 received $20 \mathrm{mg} \mathrm{Se} / \mathrm{kg}$ mineral supplement. Ovines in all groups remained untreated for 14 days, followed by a treatment period of 56 days. Selenium concentrations used in this experiment were based on the studies by LANGLANDS et al. (1990) and UNDERWOOD \& SUTTLE (1999).

Both sodium selenite and the commercial mineral diet were purchased from Ovisal ${ }^{\circledR}$ (Allnova Fanton Animal Nutrition Industry, Brazil). The commercial mineral diet contained the following concentrations of the elements per kg: $89 \mathrm{~g}$ calcium, 45 g phosphorus, $1.98 \mathrm{~g}$ sulfur, $2.5 \mathrm{~g}$ magnesium, $2,160 \mathrm{mg}$ zinc, $300 \mathrm{mg}$ manganese, $120 \mathrm{mg}$ cobalt, $8 \mathrm{mg}$ iodine, $97.5 \mathrm{~g}$ sodium, and $450 \mathrm{mg}$ fluoride (maximum), with a P205 solubility in citric acid of $95 \mathrm{mg}$ (minimum). This mineral supplement was supplied at $30 \mathrm{~g} / \mathrm{animal} / \mathrm{day}$, as recommended by the manufacturer.

Blood samples were collected after each treatment period. The serum $\mathrm{Se}$ concentration in ovines was determined by an atomic absorption technique using a graphite furnace. The semen was collected by electroejaculation after each treatment period. Seminal characteristics of the ejaculate (volume, mass movement, total motility, vigor, and sperm concentration) were analyzed according to the recommendations of CBRA (1998). Sperm morphology evaluation was carried out using a stained semen smear, following the modified Karras method (PAPA et al., 1988) and evaluated under an optical microscope according to the classification proposed by BLOM (1973).

All ovines in the five groups consumed all mixtures during the five periods of 56 days each. The amount of Se from the daily consumption of mixtures increased as each animal consumed the corresponding amounts daily. On day 0 (D0), the ovines were weighed, and samples of semen were collected for preliminary analysis before treatment. The total period of supplementation was 280 days, i.e., 5 cycles of ram spermatogenesis (56 days/each cycle), with 14 days intervals between the treatment periods, as previously described by HAFEZ \& HAFEZ (2004).

Sperm DNA fragmentation was assessed by the neutral comet assay, as described by LINFOR \& MEYERS (2002) and modified for ram sperms by MARTINS et al. (2013). For the analysis, the slides (in duplicate) were stained with $\mathrm{SYBR}^{\circledR}$ Gold aqueous 
solution (1:10,000; Invitrogen, USA) and 100 randomly selected nucleoids were scored using a fluorescence microscope connected to an image analysis system (Comet Assay IV; Perceptive Instruments, UK). The extent of DNA damage was expressed as tail intensity ( $\%$ of tail-migrated DNA). Slides treated with $10 \%$ $\mathrm{H}_{2} \mathrm{O}_{2}$ served as a positive control.

A one-way analysis of variance (ANOVA) with Tukey's post hoc test was used to analyze the differences in tail intensity among the experimental groups, with $P<0.05$ considered statistically significant. All data were analyzed using the GLM procedure in SAS.

\section{RESULTS AND DISCUSSION}

The sexual maturity of a ram is determined by sperm production, semen quality, and libido (KINBERLING \& PARSONS, 2007). According to HULET \& SHELTON (2004), ram maturity is reached at six months of age. Thus, we selected animals at ten months of age, to ensure that they were sexually mature and to standardize the age of the animals in the groups. This age of the animals also corroborates with CHACÓN et al. (2019), who reported when analyzing spermatozoa concentration and progressive motility during ram lamb development that the semen quality variables improved from six months until ten months of age, when value stabilization occurred and remained uniform until 12 months old.

The mean serum selenium concentration was significantly lower in G1 $\left(15.46 \pm 0.91 \mu \mathrm{g} / \mathrm{dL}^{\mathrm{b}}\right)$ than in the other treatment groups $(\mathrm{G} 2=20.23 \pm 0.99$ $\mu \mathrm{g} / \mathrm{dL}^{\mathrm{a}}, \mathrm{G} 3=20.79 \pm 0.94 \mu \mathrm{g} / \mathrm{dL}^{\mathrm{a}}, \mathrm{G} 4=19.94 \pm 0.92$ $\mu \mathrm{g} / \mathrm{dL}^{\mathrm{a}}$ and $\mathrm{G} 5=21.33 \pm 0.94 \mu \mathrm{g} / \mathrm{dL}^{\mathrm{a}}$ ) due to the mineral supplementation. Low-Se diets can favor DNA lesions in the spermatozoan genome, with potential implications for the offspring health (GRAUPNER et al., 2015). Selenium is a micronutrient that is necessary for testosterone biosynthesis and the normal formation and development of spermatozoa. Thus, Se deficiency can affect the testicular morphology and functions (BEHNE et al., 1996).

After each semen collection, the following spermatic parameters were analyzed: volume, mass movement, motility, vigor, spermatic concentration, and sperm morphology. All the rams exhibited values within the established standards for the species (CBRA, 1998). Results of the semen analysis were described in table 1. As for sperm evaluation, there was no statistical difference among the treatment groups in terms of the volume, mass movement, total motility, vigor, and sperm concentration $(\mathrm{P}>0.05)$. Sperm morphology differed among the treatment groups; G1 ( $0 \mathrm{mg}$ of selenium) had the highest percentage of major defects $(\mathrm{P}<0.05)$. The Se-supplemented diets $(5,10$, 15 , and $20 \mathrm{mg} / \mathrm{kg}$ mineral $\mathrm{mix} /$ animal/day) reduced the sperm morphological abnormalities that are classified as major defects, including a strongly folded tail, as well as acrosome and head defects, thereby confirming the results of BECKETT \& ARTHUR (2005). However, the percentage of minor defects did not show a statistically significant difference among the treatments $(\mathrm{P}>0.05)$. Conversely, no changes in sperm volume, mass movement, total motility, vigor, and concentration were detected.

Sperm morphology usually correlates with the genetic integrity (SAID et al., 2005, CARREIRA

Table 1 - Mean values \pm the standard error of sperm parameters including the seminal volume, mass movement, total motility, vigor, sperm concentration, and sperm defects (major and minor) of rams treated with Se (sodium selenite as inorganic Se) at 5, 10, 15 , and $20 \mathrm{mg} \mathrm{Se} / \mathrm{kg}$ mineral mix/animal/day.

\begin{tabular}{|c|c|c|c|c|c|}
\hline \multirow[t]{2}{*}{ Sperm parameters } & 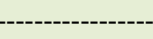 & 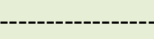 & ----Group---- & 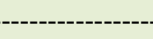 & \\
\hline & G1 & G2 & G3 & G4 & G5 \\
\hline Volume (mL) & $1.13 \pm 0.10^{\mathrm{a}}$ & $1.33 \pm 0.09^{\mathrm{a}}$ & $1.27 \pm 0.10^{\mathrm{a}}$ & $1.26 \pm 0.09^{\mathrm{a}}$ & $1.21 \pm 0.10^{\mathrm{a}}$ \\
\hline Mass moviment & $4.67 \pm 0.10^{\mathrm{a}}$ & $4.48 \pm 0.11^{\mathrm{a}}$ & $4.43 \pm 0.10^{\mathrm{a}}$ & $4.49 \pm 0.11^{\mathrm{a}}$ & $4.80 \pm 0.10^{\mathrm{a}}$ \\
\hline Total motility (\%) & $87.06 \pm 1.17^{\mathrm{a}}$ & $85.23 \pm 1.20^{\mathrm{a}}$ & $83.87 \pm 1.16^{\mathrm{a}}$ & $84.84 \pm 1.17^{\mathrm{a}}$ & $88.14 \pm 1.16^{\mathrm{a}}$ \\
\hline Vigor & $4.60 \pm 0.09^{\mathrm{a}}$ & $4.52 \pm 0.10^{\mathrm{a}}$ & $4.49 \pm 0.09^{\mathrm{a}}$ & $4.49 \pm 0.10^{\mathrm{a}}$ & $4.81 \pm 0.09^{\mathrm{a}}$ \\
\hline Concentration $\left(\mathrm{x} 10^{9}\right)$ & $1.31 \pm 0.17^{\mathrm{a}}$ & $1.88 \pm 0.16^{\mathrm{a}}$ & $1.50 \pm 0.16^{\mathrm{a}}$ & $1.29 \pm 0.15^{\mathrm{a}}$ & $1.41 \pm 0.16^{\mathrm{a}}$ \\
\hline Major defect & $11.11 \pm 1.11^{\mathrm{a}}$ & $6.93 \pm 1.17^{\mathrm{b}}$ & $7.76 \pm 1.11^{\mathrm{b}}$ & $6.39 \pm 1.12^{\mathrm{b}}$ & $5.05 \pm 1.13^{\mathrm{b}}$ \\
\hline Minor defect & $5.91 \pm 0.65^{\mathrm{a}}$ & $6.89 \pm 0.69^{\mathrm{a}}$ & $6.48 \pm 0.65^{\mathrm{a}}$ & $6.32 \pm 0.64^{\mathrm{a}}$ & $6.07 \pm 0.67^{\mathrm{a}}$ \\
\hline
\end{tabular}

Tukey test $(P<0.05)$. 
et al., 2015). Sperm DNA fragmentation has emerged as a potential causative factor of reproductive failure, and its assessment has been used as a novel laboratory tool to investigate male infertility (EVENSON, 2016, EVGENI et al., 2014). Our data showed a decrease in the spermatozoa DNA damage for Se-supplemented diet-fed animals at all tested concentrations $(5,10$, 15 , and $20 \mathrm{mg} / \mathrm{kg}$ mineral mix/animal/day) (Figure 1). Therefore, the concentration of $5 \mathrm{mg}$ of Se may be the minimum amount necessary to protect sperms during their formation. However, no animal showed any clinical signs of intoxication.

The chemopreventive effects of Se might be related to selenoproteins. Selenium is a trace and crucial element that was incorporated into selenoproteins, which have catalytic activity and act as an antioxidant (glutathione peroxidase, GPx). Recently, GRAUPNER et al. (2015) showed that selenoproteins might reduce the formation of DNA lesions. Several studies have shown that reactive oxygen species (ROS) overproduction is the main cause of apoptosis and subsequent DNA fragmentation. As an antioxidant, Se neutralizes the excessive ROS, resulting in less damage to sperm DNA (WANG et al., 2003, DOROSTKAR et al., 2012). However, despite the substantial progress made towards understanding the protective role of Se, its molecular mechanisms of action are still unknown.

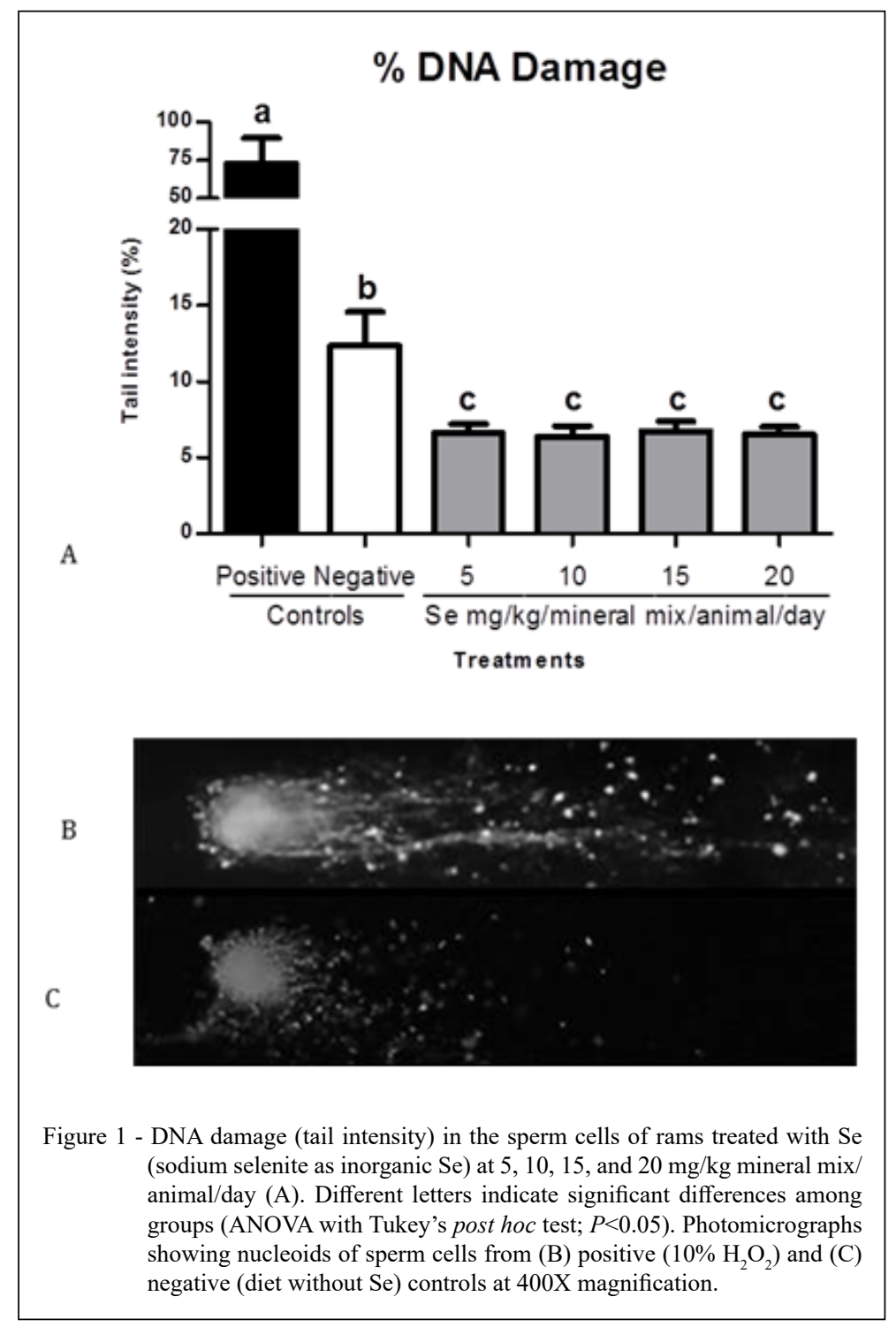

Ciência Rural, v.51, n.1, 2021. 
This paper is an initial study about the beneficial role of Se supplementation to ovine, and more studies should be carried out to evaluate the effects of this supplementation on fertility.

\section{CONCLUSION}

In conclusion, Se-supplemented diets were associated with reduced DNA damage in ram sperm cells. However, further studies using other genetic endpoints and test systems are necessary for improving our understanding of the mechanisms of Se action as a chemopreventive agent for safely maintaining ram sperm DNA integrity.

\section{ACKNOWLEDGEMENTS}

Fundação de Amparo à Pesquisa do Estado de São Paulo - FAPESP (no.51503-7) and was financed in part by the Coordenação de Aperfeiçoamento de Pessoal de Nível Superior CAPES (post-Doctoral support - CAPES/MEC no.086/2013).

\section{DECLARATION OF CONFLICT OF INTERESTS}

The authors declare no conflict of interest. The funding sponsors had no role in the design of the study; in the collection, analyses, or interpretation of data; in the writing of the manuscript, and in the decision to publish the results.

\section{AUTHORS' CONTRIBUTIONS}

The authors contributed equally to the manuscript.

\section{REFERENCES}

AGARWAL, A.; ALLAMANENI S. S. R. Sperm DNA damage assessment: a test whose time has come. Fertility and Sterility, v.84, p.850-853, 2005. Available from: $<$ https://doi.org/10.1016/j. fertnstert.2005.03.080>. Accessed: Jun. 18, 2019. doi: 10.1016/j. fertnstert.2005.03.080

BECKETT, G. J.; ARTHUR, J. R. Selenium and endocrine systems. Journal of Endocrinology, v.184, p.455-465, 2005. Available from: <https://joe.bioscientifica.com/view/journals/ joe/184/3/1840455.xml>. Accessed: Jun. 18, 2019. doi: 10.1677/ joe. 1.05971 .

BEHNE D. et al. Effects of selenium deficiency on testicular morphology and function in rats. Journal of Reproductive and Fertility, v.106, p.291-297, 1996. Available from: <https://www. ncbi.nlm.nih.gov/pubmed/8699413>. Accessed: Jun. 20, 2019. doi: $10.1530 /$ jrf.0.1060291.

BLOM, E. The ultra-structure of some characteristic sperm defects and a proposal for a new classification of the Bull spermiogram. Nordisk Veterinarer Medicin, v.53, p.83391, 1973. Available from: <https://www.ncbi.nlm.nih.gov/ pubmed/4768226>. Accessed: Jun. 20, 2019.
BOITANI, C.; PUGLISI, R. Selenium, a key element in spermatogenesis and male fertility, Advances in experimental medicine and biology, v.636, p.65-73, 2009. Available from: $<$ https://link.springer.com/10.1007\%2F978-0-387-09597-4_4>. Accessed: Jun. 20, 2019. doi: 10.1007/978-0-387-09597-4_4.

CARREIRA, J. T. et al. Impaired protamination and sperm DNA damage in a Nellore bull with high percentages of morphological sperm defects in comparison to normospermic bulls. Arquivo Brasileiro de Medicina Veterinária e Zootecnia, v.67, p.417423, 2015. Available from: <http://dx.doi.org/10.1590/16787046>. Accessed: Jun. 20, 2019. doi: 10159016787046.

CBRA Manual para exame andrológico e avaliação de sêmen animal. 2.ed. Belo Horizonte: CBRA, 1998. 49p.

CHACÓN, J. L.; et al. Characteristics of the puberty in hair ram lambs and its crosses in Colombia under low altitude conditions, Revista MVZ Córdoba, v.24, n.1, p.7097-7103, 2019. Available from: <http://www.scielo.org.co/scielo. phpscript $=$ sciarttextpid $=$ S0122-02682019000107097\#B8>. Accessed: Jun. 20, 2019. doi: 10.21897/rmvz.1413.

DOROSTKAR $\mathrm{K}$. et al. Effects of in vitro selenium addition to the semen extender on the spermatozoa characteristics before and after freezing in water buffaloes (Bubalus bubalis). Veterinary Research Forum, v.3, n.4, p.263, 2012. Available from: <https:// www.ncbi.nlm.nih.gov/pmc/articles/PMC4313046/>. Accessed: Jun. 20, 2019.

EVENSON, D. P. The sperm chromatin structure assay $\left(\mathrm{SCSA}^{\circledR}\right)$ and other sperm DNA fragmentation tests for evaluation of sperm nuclear DNA integrity as related to fertility. Animal Reproduction Science, v.169, p.56-75, 2016. Available from: <https://doi. org/10.1016/j.anireprosci.2016.01.017>. Accessed: Jun. 06, 2019. doi: 10.1016/j.anireprosci.2016.01.017.

EVGENI, E. et al. Human sperm DNA fragmentation and its correlation with conventional semen parameters. Journal of Reproduction and Infertility, v.15, p.2-14, 2014. Available from: $<$ https://www.ncbi.nlm.nih.gov/pmc/articles/PMC3955419/>. Accessed: Jun. 18, 2019.

GRAUPNER, A. et al. Genotoxic effects of two-generational selenium deficiency in mouse somatic and testicular cells. Mutagenesis, v.30, p.217-225, 2015. Available from: <https:// doi.org/10.1093/mutage/geu059>. Accessed: Jun. 08, 2019. doi: 10.1093/mutage/geu059.

HAFEZ B.; HAFEZ E. S. Reprodução animal. 7ed., Barueri: Manole, 2004. 530p.

HAWKES, W. C.; TUREK P. J. Effects of dietary selenium on sperm motility in healthy men. Journal of Andrology, v.22, p.764-772, 2001. Available from: <https://doi.org/10.1002/j.1939-4640.2001. tb02579.x>. Accessed: Jun. 08, 2019. doi: 10.1002/j.19394640.2001.tb02579.x.

HULET, C. V.; SHELTON, M. Ovinos e caprinos. In: HAFEZ, E.S.E.; HAFEZ, B. Reprodução animal. 7ed., São Paulo: Manole, 2004. p.397-41.

KINBERLING, C. V.; PARSONS, G. A. Breeding soundness evaluation and surgical sterilization of the ram. In: YOUNGQUIST, R. S.; THRElfalL, W. R. Current Therapy in Large Animal Theriogenology, 2ed., St Louis: Saunders Elsevier, 2007, p.620-628. 
KOPPEN, G. et al. The next three decades of the comet assay: a report of the 11th International Comet Assay Workshop. Mutagenesis, v.32, p.397-408, 2017. Available from: <https:// doi.org/10.1093/mutage/gex002>. Accessed: Jun. 08, 2019. doi: 10.1093/mutage/gex002.

LANGLANDS, J. P., et al. Selenium supplements for grazing sheep. A comparison between soluble salts and other forms of supplement. Animal Feed Science and Technology, v.28, p.1-13, 1990. Available from: <https://www.sciencedirect.com/science/ article/pii/037784019090063E $>$. Accessed: Jun. 05, 2019. doi: 10.1016/0377-8401(90)90063-E.

LINFOR J. J.; MEYERS S. A. Detection of DNA damage in response to cooling injury in equine spermatozoa using singlecell gel electrophoresis. Journal of Andrology, v.23, p.107-113, 2002. Available from: $<$ https://doi.org/10.1002/j.1939-4640.2002. tb02603.x>. Accessed: Jun. 05, 2019. doi: 10.1002/j.19394640.2002.tb02603.x.

MANDIKI, S. N. M. et al. Influence of season and age on sexual maturation parameters of Texel, Suffolk and Ile-de-France rams. Small Ruminant Research, v.28, p.67-79, 1998. Available from: $<$ https://doi.org/10.1016/S0921-4488(97)00073-4>. Accessed: Jun. 08, 2019. doi: 10.1016/S0921-4488(97)00073-4.

MARTINS, L. T. et al. Equine seminal plasma on preserving the viability of frozen-thawed ram sperm. Animal Reproduction, v.10, p.697-703 2013. Available from: <https://www.animalreproduction.org/article/5b5a6046f7783717068b4682>. Accessed: Jun. 05, 2019.

MATOS, C. A. et al. Genetic analyses of scrotal circumference size and growth in Rambouillet lambs. Journal of Animal Science, v.70, p.43-50, 1992. Available from: <https://doi. org/10.2527/1992.70143x>. Accessed: Jun. 08, 2019. doi: $10.2527 / 1992.70143 x$.
PAPA, F. O. et al. Coloração espermática segundo KARRAS modificada pelo emprego do barbatimão (Stryphonodendrum barbatiman). Arquivo Brasileiro Medicina Veterinária Zootecnia, v.40, p.115-123, 1988. Available from: <http://www. scielo.br/scielo.php?script $=$ sci_nlinks\&ref $=000087 \&$ pid $=$ S0103$8478201400060002600013 \& \operatorname{lng}=\mathrm{en}>$. Accessed: Jun. 20, 2019.

PETRERA, F. et al. Effect of either sodium selenite or Se-yeast supplementation on selenium status and milk characteristics in dairy goats. Small Ruminant Research, v.82, p.130-138, 2009. Available from: <https://doi.org/10.2527/1992.70143x>. Accessed: Jun. 08, 2019. doi: 10.2527/1992.70143x.

PIAGENTINI, M. Effect of selenium supplementation on semen characteristics of Brazil's ram. Reproduction in Domestic Animals, v.52, p.355-358, 2017. Available from: $<$ https://doi. org/10.1111/rda.12903>. Accessed: Jun. 08, 2019. doi: 10.1111/ rda.12903.

SAID, T. M. et al. Impact of sperm morphology on DNA damage caused by oxidative stress induced by $\beta$-nicotinamide adenine dinucleotide phosphate. Fertility and Sterility, v.83, p.95-103, 2005. Available from: <https://doi.org/10.1016/j.fertnstert.2004.06.056>. Accessed: Jun. 16, 2019. doi: 10.1016/j.fertnstert.2004.06.056.

SCHWAB, P. A. Ovinocultura Made in Brazil. 2011. Available from: <http://www.paginarural.com.br/artigo/2242/ovinoculturamade-in-brazil>. Accessed: Jun. 08, 2019

UNDERWOOD, E. J.; SUTTLE, N. F. The mineral nutrition of livestock. 3ed. Cambridge: CABI. 1999, 614p.

WANG, X. et al. Alterations in mitochondria membrane potential and oxidative stress in infertile men: A prospective observational study. Fertility and Sterility, v.80, p.844-850, 2003. Available from: $<$ https://doi.org/10.1016/S0015-0282(03)00983-X>. Accessed: Jun. 16, 2019. doi: 10.1016/s0015-0282(03)00983-x. 